\title{
Genetic parameters and genetic trends of reproduction traits in synthetic Pannon rabbits using repeatability and multi-trait animal models
}

István Nagy, István Radnai, Henrietta Nagyné-Kiszlinger, János Farkas and Zsolt Szendrő

Faculty of Animal Science, University of Kaposvár, Kaposvár, Hungary

\begin{abstract}
Genetic parameters and genetic trends of total number of born kits (TNB), and number of kits born alive (NBA) were estimated in Pannon White and Pannon Ka rabbits for the first four parities. REML and BLUP procedures were applied using repeatability and multi-trait animal models (PEST and VCE software). Heritability estimates were low for both traits and breeds and ranged between 0.06-0.07 (0.01-0.02) and 0.04-0.06 (0.02-0.02) for TNB and NBA, respectively (standard errors of estimates are given in brackets). The estimated permanent environmental effects showed higher relative importance compared to the additive genetic effects and they ranged between 0.07-0.13 (0.01-0.02) and 0.08-0.14 (0.01-0.02) for TNB and NBA, respectively. High genetic correlation coefficients were found between TNB and NBA $(0.97 \pm 0.02,0.96 \pm 0.02)$ for Pannon White and Pannon Ka, respectively. The genetic correlation coefficients estimated between TNB and between NBA of the successive parities (as separate traits) ranged between 0.64-0.97 (0.04-0.11) and 0.56-0.99 (0.03-0.10) for Pannon White and Pannon Ka, respectively. The estimated genetic trends for TNB and NBA were negligible for the Pannon White and small (0.03-0.02 [0.01-0.01]) for Pannon Ka. The mean squared errors (MSE) of the repeatability and multi-trait models were similar but the correlation coefficients of between the observed and predicted values were lower for the multi-trait $(0.27-0.61)$ than for the repeatability models $(0.43-0.65)$.
\end{abstract}

Keywords: rabbits, genetic parameters, genetic trends, reproduction traits

\section{Zusammenfassung}

\section{Genetische Parameter und genetische Tendenzen bei Reproduktionsmerkmalen von synthetischen Pannon-Kaninchen unter Verwendung von Wiederholbarkeits- und Mehrmerkmalstiermodellen}

Genetische Parameter und genetische Tendenzen der Gesamtanzahl von geborenen Kaninchenjungen (TNB) und der Anzahl von lebend geborenen Kaninchenjungen (NBA) wurden für Pannon-White- und Pannon-Ka-Kaninchen für die ersten vier Paritäten geschätzt. Dazu wurden REML- und BLUP-Verfahren unter Verwendung von Wiederholbarkeits- und Mehrmerkmalstiermodellen (PEST- und VCE-Software) eingesetzt. Die Heritabilitätsschätzwerte waren für beide Merkmale und Rassen niedrig und lagen 
zwischen 0,06-0,07 (0,01-0,02) bzw. 0,04-0,06 (0,02-0,02) für TNB bzw. NBA (Standardfehler in Klammern). Die geschätzten permanenten Umweltauswirkungen zeigten eine höhere relative Bedeutung im Vergleich zu den additiven genetischen Auswirkungen und lagen zwischen 0,07-0,13 (0,01-0,02) bzw. 0,08-0,14 (0,01-0,02) für TNB bzw. NBA. Für Pannon White bzw. Pannon Ka wurden hohe genetische Korrelationskoeffizienten zwischen TNB und NBA $(0,97 \pm 0,02 ; 0,96 \pm 0,02)$ festgestellt. Die genetischen Korrelationskoeffizienten, die zwischen TNB und zwischen NBA der aufeinanderfolgenden Paritäten (als getrennte Merkmale) abgeschätzt wurde, lagen zwischen 0,64-0,97 (0,04-0,11) bzw. 0,56-0,99 (0,03$0,10)$ für Pannon White bzw. Pannon Ka. Die geschätzten genetischen Tendenzen für TNB und NBA waren für Pannon White vernachlässigbar und für Pannon Ka klein (0,03-0,02 $[0,01-0,01])$. Die mittlere quadratische Abweichung (MSE) für die Wiederholbarkeits- und Mehrmerkmalmodelle waren vergleichbar, aber die Korrelationskoeffizienten zwischen den festgestellten und vorberechneten Werten waren für die Mehrmerkmalsmodelle $(0,27-0,61)$ geringer als für die Wiederholbarkeitsmodelle $(0,43-0,65)$.

Schlüsselwörter: Kaninchen, genetische Parameter, genetische Tendenzen, Reproduktionsmerkmale

\section{Introduction}

Litter size is a more important trait in rabbit production than in other prolific species. Current genetic schemes for rabbit meat production are based in a three way cross, in which two lines are selected for litter size in order to produce the crossbred doe and the other line is selected for growth rate in order to produce terminal sires (Blasco 1996, Khalil \& Al-Saef 2008). The different maternal rabbit lines of the different breeding programs are selected for different reproductive traits such as number of kits born alive, litter size at weaning or litter weight at weaning (or at day 21) (Khalil \& Al-Saef 2008, Mocé \& Santacreu 2010). Regardless of the chosen trait there is a general agreement in the literature that the heritability estimates of these traits are low (Blasco 1996, Khalil \& Al-Saef 2008). Considering the low heritability estimates, in order to establish efficient selection programs the best possible model has to be defined. It has to be determined whether the litter size of the successive parities are the repeated measurements of the same trait (i.e. the genetic correlation between them is $>0.8$ ). Thus the litter size records can be evaluated using either repeatability or multi-trait animal models. Although this topic has been analyzed extensively in pigs (Hamann et al. 2004, Irgang et al. 1994, Noguera et al. 2002, Roehe \& Kennedy 1995) in rabbits the available relevant literature is scarce (Baselga et al. 1992, Piles et al. 2006). Moreover the effect of the mating buck on litter size is analyzed only by few authors (Piles et al. 2006, Rastogi et al. 2000). Thus the first objective of the present study was the comparison of the repeatability and multitrait animal models using the reproductive records of the different types of Pannon rabbits of the Kaposvár University. The second objective of this study was to analyze the relative importance of the mating bucks on the Pannon rabbits' reproductive performance. 


\section{Material and methods}

\section{Foundation populations}

The development of the Pannon White rabbit breed was recently described by Nagy et al. (2010). The development of the maternal line at the Experimental rabbit farm of the Kaposvár University in Hungary started in 1995 with sperm import of a prolific genotype. The sperm was used inseminating Pannon White does but from the progeny only few breeding animals were selected. In 1999 beside individual sperm import 114 female and 48 male newborn kits of a genotype showing high reproductive performance were imported. These rabbits mated within genotype (and with Pannon White rabbits of high prolificacy) forming the base of the maternal line (called Pannon Ka). Pannon Ka was officially recognized as a new synthetic rabbit breed by the Hungarian National Institute of Agricultural Quality Control at 2003. Since then the genotype selected as a closed population (apart from individual sperm import of few bucks at 2004 and 2005) for number of kits born alive.

\section{Population management and traits recorded}

Breeding rabbits of both breeds were individually housed in a closed rabbitry (at the experimental rabbit farm of the Kaposvár University), in breeding cages. The basic area and the height of the wire net cage of the does were $84 \times 38.5 \mathrm{~cm}$ (including the $26 \times 38.5 \mathrm{~cm}$ sized nest box and feeder) and $35 \mathrm{~cm}$, respectively. The same sizes of the wire net cage of the bucks were $55 \times 43 \mathrm{~cm}$ and $40 \mathrm{~cm}$, respectively. In winter the rabbitry was heated to a minimum temperature of $15-16^{\circ} \mathrm{C}$, while - although the rabbitry is equipped with cooling panel - in the summer the temperature occasionally reached levels as high as $28^{\circ} \mathrm{C}$. All bucks were fed by the same commercial pellet (10.3 MJ DE/kg, 15.1\% crude protein, $17.2 \%$ crude fibre). During the first three weeks after kindling the does received lactation pellet (11.1 MJ DE/kg, $18.0 \%$ crude protein, $15.5 \%$ crude fibre) then it was gradually changed to starter pellet (10.4 MJ DE/kg, $16.1 \%$ crude protein, $16.9 \%$ crude fibre). Water was available ad libitum from nipple drinkers. The rabbits were first inseminated at the age of 16.5 weeks then using a 42-day long reproduction rhythm, Al occurred 11 days after kindling. The rabbits were inseminated with diluted semen (of single bucks) and the same time they were injected $1.5 \mu \mathrm{g} \mathrm{GnRH}$ analogue (Ovurelin, Reanal) to their thigh muscle. Bucks began their reproductive performance at 20 weeks of age. Does which failed to conceive were reinseminated 21 days after the unsuccessful inseminations. After 2 unsuccessful inseminations the does were culled.

To avoid mating of close relatives and high inbreeding, a circular mating system was used dividing the population of both breeds into 4 groups (Pannon White groups: 1-4, Pannon Ka groups: 5-8). After the matings all progeny received the group number of their bucks. The male progenies remained in the group but the female progenies were moved and mated

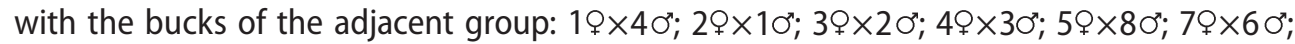
8 $8 \times 70^{*}$. The generations were overlapping.

The present analysis was based on 12494 and 3413 kindling records of 4629 Pannon White and 1316 Pannon Ka rabbit does mated to 997 Pannon White and 297 Pannon Ka sires between 1992-2010 and between 2003-2010, respectively. The total number of animals 
in the pedigree file was 6226 and 1965 for Pannon White and for Pannon Ka, respectively. Kindling records of each rabbit doe consisted of identity number, date of insemination(s), identity number of mating buck, date of kindling, total number of born kits (TNB) number of kits born alive (NBA), litter size and litter weight at 21 days after kindling. Due to the common practice of cross-fostering the analyzed traits were restricted to TNB and NBA. According to the literature the litter size of the latter parities have high correlations therefore only the first 4 parities were considered in the analysis. Descriptive statistics are presented in Table 1.

Table 1

Mean and SD of TNB and NBA in the Pannon White and Pannon Ka rabbit breeds

\begin{tabular}{ccccccccc}
\hline & & $\begin{array}{c}\text { Pannon } \\
\text { White } \\
\text { Trait }\end{array}$ & Parity & \multicolumn{2}{c}{$\begin{array}{c}\text { Pannon } \\
\text { Ka }\end{array}$} & $\begin{array}{c}\text { Pannon } \\
\text { White }\end{array}$ & $\begin{array}{c}\text { Pannon } \\
\text { Ka }\end{array}$ & \multicolumn{2}{c}{$\begin{array}{c}\text { Pannon } \\
\text { White }\end{array}$} & $\begin{array}{c}\text { Pannon } \\
\text { Ka }\end{array}$ \\
\hline TNB & 1 & 4278 & 1174 & 7.93 & 8.08 & 2.86 & 2.86 \\
& 2 & 3371 & 823 & 8.70 & 8.90 & 3.05 & 3.05 \\
& 3 & 2685 & 743 & 8.91 & 9.33 & 3.15 & 3.15 \\
& 4 & 2153 & 673 & 9.14 & 9.22 & 3.13 & 3.13 \\
& $1-4$ & 12494 & 3413 & 8.56 & 8.77 & 3.38 & 3.38 \\
NBA & 1 & 4278 & 1174 & 6.95 & 7.10 & 3.31 & 3.31 \\
& 2 & 3371 & 823 & 8.09 & 8.33 & 3.29 & 3.29 \\
& 3 & 2685 & 743 & 8.23 & 8.71 & 3.39 & 3.39 \\
& 4 & 2153 & 673 & 8.56 & 8.57 & 3.32 & 3.32 \\
& $1-4$ & 12494 & 3413 & 7.81 & 8.04 & 3.06 & 3.06 \\
\hline
\end{tabular}

TNB: total number of born kits, NBA: number of kits born alive, SD: standard deviation

\section{Statistical models}

TNB and NBA were evaluated with the REML and BLUP procedures in order to estimate genetic parameters and genetic trends. In the first evaluation bivariate repeatability animal models were used. Then the TNB and NBA records of the successive parities (1-4) were analyzed as separate traits using multi-trait animal models. The applied software was PEST (Groeneveld 1990) and VCE 5 (Kovac \& Groeneveld 2003).

In case of TNB and NBA the basic repeatability model was:

$$
y=X b+Z a+W p e+e
$$

where $y$ is the vector of observations, $b$ is the vector of fixed effects, $a$ is the vector of random animal effects, $p e$ is the random vector of permanent environmental effects, $e$ is the vector of random residual effects and $X, Z$ and $W$ are the incidence matrices relating records to fixed, animal and random permanent environmental effects, respectively.

Expected values of $\boldsymbol{a}$, pe and $\boldsymbol{e}$ were $\mathrm{E}(\boldsymbol{a})=\mathrm{E}(\boldsymbol{p} \boldsymbol{e})=\mathrm{E}(\boldsymbol{e})=0$. The variance-covariance structure was assumed to be $\mathrm{V}(a)=A \sigma_{a}^{2} \mathrm{~V}(p e)=l \sigma_{p e^{\prime}}^{2} \mathrm{~V}(e)=l \sigma_{e^{\prime}}^{2}$ and $\operatorname{cov}(a, e)=\operatorname{cov}(e, a)=0$, where $A$ is the numerator relationship matrix. Also $\operatorname{cov}(y, a)=Z A / \sigma_{a}^{2}$.

Regarding the model, the distribution of y was assumed normal, the traits were determined by many additive genes of infinitesimal effects at infinitely many unlinked loci. The alternative repeatability model contained the random effects of the mating bucks. Compared to the basic repeatability model the multi-traits models did not contain the permanent environmental 
effect and instead of the parity effect the age of the does was used as covariate (other terms were the same). The structures of the used models are given in Table 2.

To compare the repeatability and multi-trait animal models' fit mean squared error (MSE) and correlation between the observed and predicted performances $\left(r_{\hat{y i} y_{y i}}\right)$ were calculated using the PREDICT option of PEST.

Table 2

The considered factors for the examined traits in the repeatability and multi-trait models

\begin{tabular}{llcc}
\hline Factor & Type & TNB/NBA & TNB1-4/NBA1-4 \\
\hline Parity & Fixed effect & $\mathrm{x}$ & - \\
Year-month & Fixed effect & $\mathrm{x}$ & $\mathrm{x}$ \\
Animal & Animal effect & $\mathrm{x}$ & $\mathrm{x}$ \\
Permanent environment & Random effect & $\mathrm{x}$ & - \\
Age1-4 & Covariate & - & $\mathrm{x}$ \\
\hline
\end{tabular}

TNB: total number of born kits, NBA: number of kits born alive, TNB1-4: TNB at the successive parities (1-4), NBA1-4: NBA at the successive parities (1-4), Age1-4: age of the does at the successive parities (1-4)

\section{Results and discussion}

\section{Descriptive statistics}

Comparing the mean values of TNB and NBA of the analyzed breeds it can be seen that the differences were small to the advantage of the Pannon Ka (maternal line) which may be explained by the different selection criteria of the breeds. However the observed NBA of Pannon White was also lower than the reported performances of this rabbit breeds some years ago (Lévai \& Milisits 2002). Léveai \& Milisits (2002) reported higher ratio of the dead born pups in the case of non-fatty rabbits. Because the CT-aided selection of the Pannon White breed results in an increased lean production this may caused the small decrease in NBA compared to the period mentioned by Lévai \& Milisits (2002). It is worth mentioning that the highest TNB and NBA of the Pannon Ka was observed sooner (3rd parity) than recorded for Pannon White or for pigs (5th parity) (Cechova \& Tvrdon 2006).

\section{Genetic parameters}

The relative importance of additive genetic and permanent environmental effects estimated with repeatability models are presented in Table 3.

The heritability estimates of TNB were low for both breeds. Mantovani et al. (2008) received very similar value $(0.07)$ for TNB as in our study for an Italian synthetic rabbit line selected for maternal traits. Somewhat higher heritabilities (0.09-0.2) were reported by other authors (García \& Baselga 2002a, García \& Baselga 2002b, Piles et al. 2006, Rastogi et al. 2000). The differences among the heritability estimates of the different studies may be caused by the different rabbit breeds used for these studies. Moreover the applied repeatability models contained also different fixed and random factors. For the Spanish and French rabbit lines (García \& Baselga 2002a, García \& Baselga 2002b, Piles et al. 2006). A common fixed effect in the applied models was the physiological status of the does with 3 levels (nulliparous, lactating or non-lactating at mating). Contrary to these studies Rastogi et al. (2000) used 
parity as fixed effect and other random effects (maternal genetic effects, mating sire effects) that were not used by the previously mentioned authors. The estimated heritabilities for NBA were even lower than that of TNB. This phenomenon was observed by several other studies (García \& Baselga 2002a, García \& Baselga 2002b, Mantovani et al. 2008, Piles et al. 2006, Rastogi et al. 2000) where the estimated heritabilities ranged between 0.05 and 0.175 thus mostly exceeding our estimate. Beside the possible explanations mentioned so far Rastogi et al. (2000) (conducting their study at Trinidad) mentioned that in tropical environments, rabbit populations often have a heterogeneous history involving multiple breed introductions and crossings which could explain the reported relatively high heritability value (0.12). Other authors (Moura et al. 2001, Lenoir \& Garreau 2009) reported very similar values (0.04-0.05) compared to our study. The observed genetic correlation between TNBA and NBA was close to unity for Pannon White $(0.97 \pm 0.02)$ and for Pannon Ka $(0.96 \pm 0.02)$. This result was in close agreement with the finding of Mantovani et al. (2008) who reported a genetic correlation of 0.97 between these traits. This result suggests that increasing the NBA will also result in a higher number of stillborn kits. Moreover Mantovani et al. (2008) estimated an unfavourable genetic correlation (0.62) between NBA and mortality \% up to weaning indicating a negative trend in decreasing the number of weaned kits with the enhancement of the NBA.

Table 3

Heritability estimates and relative importance of permanent environmental and mating buck effects in the Pannon White and Pannon Ka rabbit breeds (standard errors of estimates are given in brackets)

\begin{tabular}{llcccc}
\hline & & \multicolumn{2}{c}{ Basic model } & \multicolumn{2}{c}{ Alternative model } \\
& & TNB & NBA & TNB & NBA \\
\hline Pannon Wite & $\mathrm{h}^{2}$ & $0.07(0.01)$ & $0.06(0.01)$ & 0.07 & 0.06 \\
& $\mathrm{pe}$ & $0.07(0.01)$ & $0.08(0.01)$ & 0.07 & 0.08 \\
\multirow{3}{*}{ Pannon Ka } & $\mathrm{mb}$ & - & - & 0.00 & 0.00 \\
& $\mathrm{~h}^{2}$ & $0.06(0.02)$ & $0.04(0.02)$ & 0.06 & 0.04 \\
& $\mathrm{pe}$ & $0.13(0.2)$ & $0.14(0.02)$ & 0.13 & 0.14 \\
& $\mathrm{mb}$ & - & - & 0.01 & 0.006 \\
\hline
\end{tabular}

TNB: total number of born kits, NBA: number of kits born alive, pe: permanent environmental effects, mb: mating buck effects

The estimated heritabilities for TNB and NBA using multi-trait animal models are provided in Table 4.

It can be seen that the heritabilities showed no trend with the increasing parity number. The topic whether the genetic background of litter size was the same after the successive parities was first investigated in rabbits by Baselga et al. (1992). Baselga et al. (1992) conducted a series of univariate models for NBA of the first three parities and found the highest $h^{2}$ at the first parity $(0.10-0.14)$ compared to the second and third parities (0.01-0.07). Based on these findings Baselga et al. (1992) suggested that genetic correlations among the NBA of the successive parities were possibly lower than unity. However, as Baselga et al. (1992) did not use multivariate models the observed results estimates may be biased for the latter parities because not all information on selection was used simultaneously in the analyses. In pigs using univariate or bivariate analyses Roehe \& Kennedy (1995) and Irgang et al. (1994) found that heritability increased with advancing age which tendency was opposite compared to Baselga et al. (1992). In pigs Alfonso et al. (1997) conducted bivariate and multi-trait analyses 
for TNB and NBA of the first 5 parities. Based on their results no trend was observed for the heritabilities with the advancing parity number. In accordance with Alfonso et al. (1997) Piles et al. (2006) did not found any tendency for the heritability estimates with the advancing age using multi-trait models.

Table 4

Estimated heritabilities (diagonals) and genetic correlations (off-diagonals) of TNB and NBA in subsequent kindlings of the Pannon White and Pannon Ka rabbit breeds (standard errors of estimates are given in brackets)

\begin{tabular}{|c|c|c|c|c|c|}
\hline & 1 & 2 & 3 & 4 & TNB \\
\hline \multirow[t]{4}{*}{ Pannon White } & $0.12(0.02)$ & $0.89(0.05)$ & $0.68(0.05)$ & $0.64(0.08)$ & 1 \\
\hline & & $0.12(0.02)$ & $0.91(0.04)$ & $0.91(0.05)$ & 2 \\
\hline & & & $0.19(0.02)$ & $0.93(0.04)$ & 3 \\
\hline & & & & $0.11(0.01)$ & 4 \\
\hline \multirow[t]{5}{*}{ Pannon Ka } & $0.19(0.03)$ & $0.75(0.11)$ & $0.74(0.08)$ & $0.80(0.09)$ & 1 \\
\hline & & $0.23(0.04)$ & $0.82(0.08)$ & $0.92(0.05)$ & 2 \\
\hline & & & $0.31(0.03)$ & $0.97(0.02)$ & 3 \\
\hline & & & & $0.24(0.04)$ & 4 \\
\hline & 1 & 2 & 3 & 4 & NBA \\
\hline \multirow[t]{4}{*}{ Pannon White } & $0.14(0.02)$ & $0.90(0.04)$ & $0.68(0.06)$ & $0.56(0.10)$ & 1 \\
\hline & & $0.14(0.02)$ & $0.91(0.03)$ & $0.86(0.06)$ & 2 \\
\hline & & & $0.17(0.01)$ & $0.96(0.05)$ & 3 \\
\hline & & & & $0.12(0.02)$ & 4 \\
\hline \multirow[t]{4}{*}{ Pannon Ka } & $0.13(0.04)$ & $0.98(0.04)$ & $0.71(0.11)$ & $0.79(0.12)$ & 1 \\
\hline & & $0.09(0.02)$ & $0.82(0.13)$ & $0.88(0.12)$ & 2 \\
\hline & & & $0.26(0.05)$ & $0.99(0.02)$ & 3 \\
\hline & & & & $0.18(0.04)$ & 4 \\
\hline
\end{tabular}

TNB: total number of born kits, NBA: number of kits born alive

The genetic correlations among the TNB and NBA of the successive parities were high (generally above 0.8) (Table 4) especially for the adjacent parities. For the Pannon White breed the estimated genetic correlation coefficients decreased with the increasing time gap between the different parities. The lowest estimates were obtained between the first and fourth parities for TNB (0.64) and NBA (0.56). For the Pannon Ka breed this tendency was less pronounced probably due to the lower amount of the available data. In a similar study conducted in pigs the genetic correlations reported by Alfonso et al. (1997) were high in case of the bivariate analyses (generally higher than 0.8) but were much lower when multi-trait models were used (0.16-0.74). In rabbits multi-trait models were used only by Piles et al. (2006) to analyze TNB and NBA of the successive parities. For the genetic correlations among TNB and NBA of the successive parities the authors found high estimates in the A-line generally equal or greater than 0.8 . In the other two lines the estimates were much lower for TNB (0.53-0.84) and NBA (0.39-0.82). Based on these results different genes or combinations of genes could be involved in the determination of litter size at the first, second and successive parities. Therefore different parities may be treated as different traits when genetic evaluations are performed (Piles et al. 2006). However, Piles et al. (2006) also noted that BLUP is not robust to errors in the estimation of genetic parameters. Genetic correlations have greater errors than heritabilities and are 
more difficult to estimate. Thus a multiple-trait model has a greater risk of giving wrong estimates than a repeatability model.

The estimated relative importance of permanent environmental effects was somewhat higher for TNB and NBA than that of the additive genetic effects (Table 3). The magnitude of our estimates were inside the range to that $(0.07-0.22)$ of the previously mentioned authors. The alternative repeatability model that included the effects of the mating buck did not finished with optimal convergence status therefore the standard errors could not be obtained (Table 3). Nevertheless it can be seen that the relative importance of these effects were negligible for Pannon Ka and were zero for Pannon White. The mating buck effects were analyzed only by few authors in rabbits (Piles et al. 2006, Rastogi et al. 2000) and similarly to our study they reported that the relative importance due to random effect of service sire was very low (0.01-0.03). Piles et al. (2006) similarly to the present study decided not to use this effect in the multi-trait models. On the contrary in pigs although the effect of service sire was also very low authors suggested to include this effect in the model of TNB (Serenius et al. 2003) and NBA (Hamann et al. 2004) to improve accuracy of breeding value prediction and to get an efficient tool for phenotypic selection of Al boars due to poor piglet production.

\section{Genetic trends}

The estimated annual genetic trends were low for both traits in Pannon Ka (repeatability model) and were negligible for Pannon White (Table 5).

Table 5

Estimated genetic trends of TNB and NBA in the Pannon White and Pannon Ka rabbit breeds (standard errors of estimates are given in brackets)

\begin{tabular}{|c|c|c|c|}
\hline & \multirow[b]{2}{*}{ Parity } & \multicolumn{2}{|c|}{ Repeatability model } \\
\hline & & TNB & NBA \\
\hline Pannon White & $1-4$ & $0.008(0.002)$ & $0.01(0.002)$ \\
\hline \multirow[t]{3}{*}{ Pannon Ka } & & $0.03(0.01)$ & $0.02(0.01)$ \\
\hline & & \multicolumn{2}{|c|}{ Multivariate model } \\
\hline & Parity & TNB & NBA \\
\hline \multirow[t]{4}{*}{ Pannon White } & 1 & $-0.000002(0.000003)$ & $7.036062 \mathrm{E}-7(0.000002)$ \\
\hline & 2 & $-0.000002(0.000002)$ & 9.695047E-8 (0.000002) \\
\hline & 3 & $0.0002(0.0001)$ & $0.0002(0.0001)$ \\
\hline & 4 & $0.00002(0.00001)$ & $0.000021(0.00001)$ \\
\hline \multirow{4}{*}{ Pannon Ka } & 1 & $0.00003(0.00003)$ & $0.00002(0.00004)$ \\
\hline & 2 & $-0.00005(0.00004)$ & $-0.000002(0.00002)$ \\
\hline & 3 & $0.00007(0.00003)$ & $0.002(0.001)$ \\
\hline & 4 & $0.00004(0.00001)$ & $0.0002(0.0002)$ \\
\hline
\end{tabular}

TNB: total number of born kits, NBA: number of kits born alive

The latter breed is not selected for reproductive traits but the observed trend of the Pannon Ka breed is perhaps lower than expected. Moura et al. (2001) received the same annual trend for NBA (0.03 rabbits/year) and similar magnitude of correlated response $(0.5 \mathrm{kits} / 10$ generations) were found by Santacreu et al. (2005) as the result of selection for uterine capacity. On the contrary French and Spanish rabbit lines showed higher genetic trends for 
NBA (0.11-0.17 rabbis/generation and 0.12 rabbits/year) (Garreau et al. 2005, García \& Baselga 2002a, García \& Baselga 2002b, Lenoir \& Garreau 2009). The differences may be explained by the higher heritabilites found by these studies compared to our results. As de Rochambeau et al. (1998) demonstrated when heritability estimate increases the estimated genetic trend also goes up. Thus the small magnitude of the genetic trend of the present study was probably the consequence of the low NBA and TNB heritabilities estimated in the Pannon White and Pannon Ka populations. García \& Baselga (2002a, 2002b) used a cryopreserved population to determine the selection response of NBA which was almost identical $(0.086 \mathrm{vs} .0 .09)$ with the estimated genetic trend according to García \& Baselga (2002a) but the selection response and the estimated genetic trend differed greatly (0.085 vs. 0.175$)$ according to García \& Baselga (2002b). However, as Blasco (1996) and de Rochambeau et al. (1998) noted that when the heritability is small and when the generations do not overlap, the response estimated with a control strain (e.g. using cryopreservation) is preferable. The regression line through the average genetic values per generation/year fit better in case of overlapping generations (as it was the case for the Pannon rabbit populations).

\section{Fit of the models}

The fit of the used models are presented in Table 6. Generally the estimated MSE values of the repeatability and multi-trait models did not differ much but the correlation coefficient between the observed and predicted TNB and NBA were lower for the multi-trait models than that of the repeatability models.

Based on the genetic correlation coefficients estimated between the TNB and NBA of the successive parities and on the parameters evaluating the different (repeatability and multitrait) models' fit the authors of the present study advocate the use of the repeatability models.

Table 6

Comparison of the different models' fit of TNB and NBA in the Pannon White and Pannon Ka rabbit breeds

\begin{tabular}{|c|c|c|c|}
\hline & \multirow[b]{2}{*}{ Parity 1-4 } & \multicolumn{2}{|c|}{ Repeatability model } \\
\hline & & TNB & NBA \\
\hline \multirow[t]{2}{*}{ Pannon White } & MSE $^{1}$ & 7.70 & 9.55 \\
\hline & $r_{\hat{y i l}^{\prime} y_{i}^{2}}^{2}$ & 0.46 & 0.43 \\
\hline \multirow[t]{4}{*}{ Pannon Ka } & MSE & 5.01 & 6.88 \\
\hline & $r_{\text {yityi }}$ & 0.65 & 0.62 \\
\hline & & \multicolumn{2}{|c|}{ Multivariate model } \\
\hline & Parity $1,2,3,4$ & TNB & NBA \\
\hline \multirow[t]{2}{*}{ Pannon White } & MSE & $7.57 ; 8.75 ; 9.02 ; 9.22$ & $7.21 ; 8.44 ; 8.65 ; 8.87$ \\
\hline & $r_{v i v i}$ & $0.27 ; 0.30 ; 0.33 ; 0.41$ & $0.27 ; 0.31 ; 0.34 ; 0.39$ \\
\hline \multirow{2}{*}{ Pannon Ka } & MSE & $5.85 ; 6.79 ; 7.05 ; 6.45$ & $4.75 ; 5.60 ; 4.85 ; 5.42$ \\
\hline & $r_{\text {yi,yi }}$ & $0.48 ; 0.32 ; 0.32 ; 0.36$ & $0.59 ; 0.44 ; 0.61 ; 0.46$ \\
\hline
\end{tabular}

TNB: total number of born kits, NBA: number of kits born alive, MSE: mean squared error, $r_{\hat{y} i, y i}$ : correlation between the observed and predicted performances

\section{Acknowledgements}

Financial support of Bolyai Research Grant (BO/00659/08/04) is gratefully acknowledged. 


\section{References}

Alfonso L, Noguera JL, Babot D, Estany J (1997) Estimates of genetic parameters for litter size at different parities in pigs. Livest Prod Sci 47, 149-156

Baselga M, Gómez E, Cifre P, Camacho J (1992) Genetic diversity of litter size traits between parieties in rabbits. J Appl Rabbit Res 15, 198-205

Blasco A (1996) Genetics of Litter size and does fertility in the rabbit. In: Proc 6th World Rabbit Congress, Toulouse, France, Vol 2., 219-227

Cechova M, Tvrdon Z (2006) Relationships between backfat thickness and parameters of reproduction in the Czech Large White sows. Arch Tierz 49, 363-369

De Rochambeau H, Duzert R, Tudela F (1998) Long term selection experiment in rabbit. Estimation of genetic progress on litter size at weaning. In: Proc 6th World Cong. Appl. Livest. Prod. Armidale, Australia, Vol 26., $112-115$

García ML, Baselga M (2002a) Estimation of genetic response to selection in litter size of rabbits using a cryopreserved control population. Livest Prod Sci 74, 45-53

García ML, Baselga M (2002b) Genetic response to selection for reproductive performance in a maternal line of rabbits. World Rabbit Sci 10, 71-76

Garreau H, Duzert R, Tudela F, Baillot C, Ruesche J, Grauby G, Lille-Larroucau C, de Rochambeau H (2005) Gestation et sélection de la souche INRA 1777: Résultats de trois générations de séléction. In: Proc 12èmes Journées de la Recherche Cunicule, 29-30 novembre, Paris, France

Groeneveld E (1990) PEST Users' Manual. Institute of Animal Husbandry and Animal Behaviour Federal Research Centre, Neustadt, Germany, 1-80

Hamann H, Steinheuer R, Distl O (2004) Estimation of genetic parameters for litter size as a sow and boar trait in German herdbook Landrace and Pietrain swine. Livest Prod Sci 85, 201-207

Irgang R, Fávero JA, Kennedy BW (1994) Genetic parameters for litter size of different parities in Duroc, Landrace, and Large White sows. J Anim Sci 72, 2237-2246

Khalil MM, Al-Saef AM (2008) Methods, criteria,techniques and genetic responses for rabbit selection: a review. In: Proc. 9th World Rabbit Congress, Verona, Italy, 1-22

Kovac M, Groeneveld E (2003) VCE-5 Users' Guide and Reference Manual Version 5.1. University of Ljubljana, Biotechnical Faculty, Department of Animal Science, Domzale, Slovenia, Institute of Animal Science Federal Agricultural Research Centre, Neustadt, Germany, 1-68

Lenoir G, Garreau H (2009) Estimation de paramèters génétiques de la fertilité et du nombre de laperaux nés vivant chez des lapins d'une lignée femelle Hycole. In: Proc. 13èmes Journées de la Recherche Cunicule, 17-18 novembre, Le Mans, France

Lévai A, Milisits G (2002) Effect of selection on body fat content by means of the TOBEC method on some reproductive traits of rabbit does and on the body composition of growing rabbits. Arch Tierz 45, 403-411 [in German]

Mantovani R, Sartori A, Mezzadri M, Lenarduzzi M (2008) Genetics of maternal traits in a new synthetic rabbit line under selection. In: Proc. 9th World Rabbit Congress, Verona, Italy, 169-174

Mocé ML, Santacreu MA (2010) Genetic improvement o flitter size in rabbits. In: Proc. 9th WCGALP Leipzig, Germany, CD Comm. No. 0025

Moura ASAMT, Costa ARC, Polastre R (2001) Variance components and response to selection for reproductive litter and growth traits through a multi-purpose index. World Rabbit Sci 9, 77-86

Nagy I, Curik I, Radnai I, Cervantes I, Gyovai, P, Baumung, R, Farkas, J, Szendrő ZS (2010) Genetic diversity and population structure of the synthetic Pannon White rabbit revealed by pedigree analyses. J Anim Sci 88, 1267-1275

Noguera JL, Varona L, Babot D, Estany J (2002) Multivariate analysis of litter size for multiple parities with production traits in pigs: I. Bayesian variance component estimation. J Anim Sci 80, 2540-2547 
Piles M, García ML, Rafel O, Ramon J, Baselga M (2006) Genetics of litter size in three maternal lines of rabbits: Repeatability versus multiple-trait models. J Anim Sci 84, 2309-2315

Rastogi RK, Lukefahr SD, Lauckner FB (2000) Maternal heritability and repeatability for litter traits in rabbits in a humid tropical environment. Livest Prod Sci 67, 123-128

Roehe R, Kennedy BW (1995) Estimation of genetic parameters for litter size in Canadian Yorkshire and Landrace swine with each parity of farrowing treated as a different trait. J Anim Sci 73, 2959-2970

Santacreu MA, Mocé ML, Climent A, Blasco A (2005) Divergent selection for uterine capacity in rabbits. II. Correlated response in litter size and its components estimated with a cryopreserved control population. J Anim Sci 83, 2303-2307

Serenius T, Sevón-Aimonen ML, Mäntysaari EA (2003) Effect of service sire and validity of repeatability model in litter size and farrowing interval of Finnish Landrace and Large White populations. Livest Prod Sci 81, 213-222

Received 11 September 2010, accepted 24 February 2011.

Corresponding author:

István Nagy

email: nagy.istvan@ke.hu

Department of Agricultural Product Processing and Qualification, Faculty of Animal Science, 40. Guba S. str. Kaposvár 7400, Hungary 